\title{
TRANSPARENCY-BUILDING IN THE SECURITY SECTOR
}

$\mathrm{I}$

$\mathrm{n}$ the past several years, a fairly substantial non-governmental expertise on defence and security matters emerged in Bulgaria. It has already made significant contribution to the reform efforts in the national security sector. Building on the available expertise, a group of non-governmental think-tanks launched the publication of Security Focus and Security Sector Watch, a newsletter devoted to the problems of security sector transformation. This newsletter was created as part of the effort to transform the security environment and the security sector in South-East Europe and specifically in Bulgaria. This goal can be achieved through the generation of knowledge about the problems of security sector reform; the use of modern information technologies in the sector; democratic control over the security sector and transparency of security policies; regional cooperation in the context of the Euro-Atlantic integration; network building; and, dissemination of knowledge.

The newsletter supports and publicizes modern thinking and approaches to security policies. It is a venue for discussions of concepts and policies in an area which experienced fundamental change starting even before the end of the Cold War but becoming most conspicuous after the events of 11 September 2001. The newsletter seeks to be one of the main tools for spreading ideas and participation in setting the agenda of the security sector transformation process. It consists of four sections:

- Security Environment - monitors and analyses issues in the national and international security environment;

- Security Sector - analyses the processes in the national security sector and evaluates its transformation;

- By Invitation - provides a venue for opinions on current security issues; and

- Current Events - lists current and upcoming events related to the national security sector.

The newsletter is published by the George C. Marshall Association-Bulgaria, <www.GCMarshall.bg>, Institute for Euro-Atlantic Security, <ww.ieas-bg.org>, 
and Mediapool.bg, <http://www.mediapool.bg/>, as part of a project of the Open Society Foundation-Sofia, <www.osf.bg>. It not only provides analyses and specific recommendations for reform, but also seeks to stimulate debates about key issues in the security sector involving experts as well as all those interested in the country's modernization and prosperity. Hence, the publishers look forward to receiving comments about the ideas in this publication and welcome outside participation in the efforts to attain the newsletter's objectives.

All current and past issues of the newsletter can be read in both Bulgarian and English at http://www.mediapool.bg/site/security/. Direct link to the English language edition: http://www.mediapool.bg/site/security/index_en.shtml. 